\title{
BASIC PRINCIPLES IN SOVIET SPACE LAW: PEACEFUL COEXISTENCE, PEACEFUL COOPERATION, AND DISARMAMENT
}

\author{
Robert D. Crane*
}

During recent years the Soviets have increasingly used law as a subtle but effective instrument to control the minds of men and thereby to prepare the general political environment for the more effective execution of Soviet policy. International law has become for the Soviets a potential matrix and framework for the entire Soviet policy of world revolution. Space law has become a particularly important part of the developing science of Soviet international law, because it serves to prepare the way for Communist military use of space to deter effective Western military opposition to Communist expansion here on earth.

\section{I}

\section{Peaceful Coexistence}

The strategic doctrine which the Communists have adopted to pursue their expansionist foreign policies is known in the new Communist jargon as "peaceful coexistence." It is important to understand the nature of this revolutionary doctrine, because it determines all the basic principles of Soviet space law. In the introduction to the second symposium of the Space Law Commission of the Soviet Academy of Sciences, edited by G. P. Zhukov, the Deputy Chairman of the Soviet Space Law Commission, Professor G. P. Zadorozhnyy, stated that "every activity in outer space whatsoever which is incompatible with the principle of peaceful coexistence is illegal."1

Some scholars in the West believe that Soviet support of peaceful coexistence reflects, as Professor Edward McWhinney puts it, a "common interest in minimum rules of world order," and "a sort of nuclear age 'due process' governing fundamental East-West relations." Professor McWhinney, who is a Canadian member of the International Law Association and a member of its committee charged with the study of peaceful coexistence, believes that this is particularly true after the Cuban crisis. He has stated that there is, to be sure, a "hard-line, neo Stalinist core of Soviet juristic thinking which would use peaceful coexistence as no more than a convenient camouflage for achieving 'proletarian internationalism' in the special

- A.B. 1955, Northwestern University; LL.B. 1959, Harvard University. Research Principal of 'The Center for Strategic Studies, and Chairman of its Study Program on Arms Control, Georgetown University.

${ }^{1}$ Zadorozhnyy, In Honor of the Seventieth Birthday of Yevgeniy Aleksandrovich Korovin (in Russian), in G. P. Zhukov (ED.), Kosmos I MeZhduNarodnoye sotrudnichestvo 8 (1963). All translations from the Russian, unless otherwise indicated, are by the author.

"McWhinney, "Coexistence," the Cuban Crisis, and Cold War International Law, International Journal, Win. $1962-63$, p. 68 . 
sense of coordinated world revolution."3 He contends that this conflicts with "the currently orthodox Soviet thinking on peaceful coexistence, associated with Premier Khrushchev . . . which bears some comparisons obviously to Leninist notions of 'Socialism in one country.'" Professor McWhinney adds:

Peaceful coexistence, as so developed by Soviet jurists and policy-makers, is, of course, a somewhat static, conservative, even reactionary doctrine. .. . For peaceful coexistence in this sense amounts virtually to a legitimation of the political and military status quo of the cold war era. In so far as it would accept the de facto situation of the bi-polar division of the world into the two great military blocs dominated respectively by the United States and the Soviet Union, it would necessarily concede general control and responsibility by each bloc leader over its own sphere of influence. It would further proclaim a principle of non-interference by either the United States or the Soviet Union in the other's bloc, however great the temptation to profit by the other side's difficulties at any time might be, and however great the moral anguish at not being able to intervene in specific cases. ${ }^{4}$

I quote this statement by Professor McWhinney because it is the clearest statement I have ever encountered of exactly what "peaceful coexistence" is not, and because it conflicts completely with the Soviet's own definition of peaceful coexistence.

A colleague of mine at the Center for Strategic Studies, Richard Allen, has presented in some detail the Communists' own views on peaceful coexistence in a chapter he has written for the book, Detente: Cold War Strategies in Transition." It would be enlightening to ponder the Communists' own statements on the subject of peaceful coexistence which Professor Allen has made available to scholars in the field.

A recent Communist book by $\mathrm{H}$. Dona on peaceful coexistence published last year explains that "some try to reduce the notion of peaceful coexistence to the renunciation of war. But peace and peaceful coexistence are not one and the same thing." The Soviet author Shishlin comments on the detente following the recent test-ban treaty as follows:

In view of the Communists, peaceful coexistence between the two systems is certainly not a passive process in which there is some sort of parallel development of capitalism and socialism, no freezing of social relationships, or strengthening of the status quo in the relationship between the forces of socialism and capitalism, but an active and intense struggle, in the course of which socialism irresistibly attacks, while capitalism suffers one defeat after another. ${ }^{8}$

The above quoted book by Dona states that "the struggle of the people against reactionary regimes cannot be dissolved by international agreement. For this struggle to cease, the causes eliciting it must be eliminated, i.e., capitalism must be liquidated."

\footnotetext{
sId. at 69-70.

Id. at $7 \mathrm{r}-72$.

"Allen, Peace or Peaceful Coexistence?, in Eleanor Lansing Dulles \& Robert D. Crane (Eds.), Detente: Cold War Strategies in Transition 23-62 (r964).

${ }^{\circ}$ See the discussion in Allen, supra note 5, at 30.
} 
In the deterministic framework of Communist thinking, which most nonCommunists find impossible to take seriously or even to understand, capitalism actually causes the Communists to wage a struggle against it, and therefore capitalism must be destroyed to stop the struggle. As Premier Khrushchev put it in August rg63 following the signing of the nuclear test ban treaty:

If everyone acted and thought in the Communist way then there would be no antagonistic classes and communism would already be victorious everywhere. However, while there are still two systems, socialists and capitalists, each system has its own policy, its own course, and we cannot but take into account the fact that two systems exist. A fight is in progress between these two systems, a life and death combat. But we Communists want to win this struggle with the least losses [note that he does not exclude the necessity for losses] and there is no doubt whatsoever that we shall win.

Perhaps the best definition of peaceful coexistence by a Western student of the subject was given by Richard Allen, as follows:

Peaceful coexistence is to the Communists a unilateral strategic doctrine, which is imposed upon the "inevitably doomed" adversary through the combined inherent and physical "superiority" of the Communist system, and to which the adversary may only "respond" because he is denied a creative and participating role in determining its essence and application. ${ }^{8}$

This creative role of "peaceful coexistence" must be emphasized because the essence of peaceful coexistence is its revolutionary and aggressive nature, its commitment to total victory by whatever means are best suited under the given circumstances. These means include the use of armed force and nuclear blackmail whenever the Communists believe that the risks of such use are outweighed by the gains which may be achieved. The Cuban crisis, and any crises we may have in the future, are not necessarily aberrations from peaceful coexistence, but result merely from a specific application of this doctrine, perhaps sometimes unsuccessfully, in a given time and place. The remarkable thing about peaceful coexistence is that it is growing in complexity and sophistication to encompass almost anything the Soviets may want to do in pursuit of their goal of total global victory.

The most interesting development for the American lawyer and political scientist is the Soviet attempt to clothe peaceful coexistence in legal terms. The dean of Soviet space lawyers, Professor Yevgeniy Korovin, stated last April that

One of the consequences of Socialism's transformation into the decisive factor of international relations is that peaceful coexistence has gradually become an accepted principle of international law. Initially it was the expression of a peaceful "breathing space," but being a specific form of class struggle between Socialism and capitalism on an international scale, peaceful coexistence was filled with new content as the relation of world forces changed. ${ }^{9}$

${ }^{7}$ Nikita S. Khrushchev, Speech at the Soviet-American Hungarian Meeting, July I9, 1963, in Current Sovict Documents, Aug. I9, 1963, pp. 9, I3.

Allen, supra note 5, at 33 .

- Korovin, An Old and Futile Demand, International Affairs (Moscow), No. 4, at roo (1963). 
In an earlier address to the Advisory Council of the University of Moscow Law School in I96r, which first set forth the essence of the new international law of "peaceful coexistence," Professor Korovin stated that the time had come for Soviet international lawyers to wage what he termed an "offensive attack," that they should "proceed from our own concepts, from the democratic principles of international law, and then, having proclaimed their binding character and universality, to show that any theories hostile to them constitute a violation of the generally recognized and therefore generally binding principles of law...."10

The implication for Soviet space law was clearly stated in the new Soviet space law symposium, as quoted earlier, that "every activity in outer space whatsoever which is incompatible with the principle of peaceful coexistence is illegal." If the task of peaceful coexistence is to ensure that communism triumphs over capitalism as quickly and as effectively as possible, the resistance which the non-Communist world may put up is basically contradictory to "law" and hence is "illegal."

II

\section{Peaceful Cooperation}

The second basic principle in Soviet space law, according to the introduction to the new Soviet space law symposium is "peaceful cooperation."11 This principle has evoked considerable discussion among Soviet international lawyers because the initial dispute back in $195^{6}$ among Soviet and American international lawyers over "peaceful coexistence" arose from the the Soviet opposition to Western lawyers who wanted to replace the term "peaceful coexistence" with the term "peaceful cooperation." The Westerners preferred the term "peaceful cooperation" in order to portray the Western concept of increasing reliance on mutuality of interest in foreign affairs and to portray the idea that international institutions for conflict resolution should replace unilateral conflict management as the ordering element of international relations.

This problem received a thorough airing last year at the Sixth Annual Meeting of the Soviet Association of International Law. Movchan led off the discussion by a speech on the legal principles of peaceful coexistence, in which he reminded his listeners that the 196r Program of the Communist Party of the Soviet Union foresees a real possibility that new principles put forth by socialism will triumph over the principles of aggressive imperialist states. He suggested that the codification of international law should serve to make the content of the existing principles and norms conform to the developmental laws of contemporary society, by which he meant the shift of the correlation of forces in favor of Communism. Movchan evoked considerable criticism by stating that the principle of friendly relations among states-and by implication "peaceful cooperation"-is the same as peaceful co-

\footnotetext{
${ }^{10}$ Korovin, The Declaration of the Conference of Representatives of Communist and Workers' Parties and the Tasks of the Science of International Law (in Russian), [196I] VEstnix Moskovskoco UN1versiterta 7x-72. See also the discussion in Crane, Soviet Attitude Totvard International Space Law, 56 AMr. J. INT'L L. 685, 713 (I962).

${ }^{11}$ ZADOROZHNYY, supra note $\mathrm{I}$, at 8.
} 
existence. The critics, of course, objected that such a confusion of terms would ignore the character of the relationship of class warfare between the socialist and capitalist states. After all, as Zakharova had pointed out:

Contemporary international law, which regulates the relations both of socialist and capitalist states, does not require the establishment among such states of relations of broad and full cooperation and fraternal mutual assistance, because by virtue of the very nature of capitalist states such relations are impossible. ${ }^{12}$

The solution to this problem was suggested at the Sixth Annual Meeting of the Soviet Association of International Law by V. M. Koretsky, who is presently the Soviet judge in the United Nations' principal legal organ, the International Court of Justice. Mr. Koretsky pointed out, as indeed Mr. Tunkin had done himself on November 2I, Ig6r, in the Sixth Committee of the United Nations, that the essence of peaceful coexistence as a doctrine must be distinguished from the principles of peaceful coexistence put forward as principles of international law. Koretsky stated that peaceful coexistence in its essence and intent is an historical category of class warfare, but that the legal principles put forth under the rubric of peaceful coexistence can permit compromises with capitalism to achieve agreements under specific circumstances to strengthen the peace, because "it is necessary to consider not only one's intentions but one's possibilities" at the present moment.

In effect Koretsky was reminding the Soviet international lawyers that Marxism distinguishes between strategy and tactics. The support of "peaceful coexistence" as a Communist term and "peaceful cooperation" as a term to use in dealing with the capitalists is quite consistent with the Leninist policy of dealing simultaneously with the proletariat and with the bourgeoise as explained in his treatise entitled The Two Tactics of Social Democracy. This technique is discussed both in Stalin's work, Problems of Leninism, and in the standard work on Fundamentals of Marxism-Leninism, the most recent edition of which was published last year.

The concepts of interdependence and supranational institutions, such as the United Nations and the International Court of Justice, which many Westerners consider to be basic elements and instruments of international cooperation, were attacked in the recent Zhukov symposium on space law, which specifically rejected the concept of a single global communications satellite system. They were also attacked at a recent Conference of International Lawyers in Moscow devoted to the discussion of legal order in a disarmed world. This conference, which was sponsored by the Commission on Legal Problems of Disarmament of the Soviet Committee on the Defense of the Peace, was reported in the October $x 963$ issue of Soviet State and Law. At this conference, Levin stated that as long as states of two different systems existed, international organizations with wide supranational powers would be impossible, because such organizations, as has been proven in the West, interfere with the internal affairs of states.

${ }^{12}$ Zakharova, Bilateral Treaties of Friendship, Cooperation and Mutual Aid Among Socialist States (in Russian), [rg62] Sovetskoye Gosudarstvo I Pravo, No. 2, at 80, 83 (1962). 
The clearest Soviet statement on this problem is contained in an article by Solodovnikov:

It is stated that the development of the weapons of mass annihilation and the simplification of their manufacture will impel the two systems to seek points of "convergence" and agree to international inspection which will gradually grow into a "world government" placed above the still raging cold war.

This, it appears, is the end aim of "convergence," this is the path to salvation suggested by the apologists of capitalism.

The concept of a future in which capitalism and Communism will "converge" on an "equal footing" is Utopian through and through. The time will come, of course, when there will be a world government, but it will be the government of a world Socialist community in which there will be no place either for "free enterprise" or for the monopolies. Neither research nor the subtle sophisms of the apologists of capitalism can save it from the death predestined for it by history. ...

Life will always smash the advocates of ideological compromises and their bleak illusions and attempts to find a "third way" in the struggle of the two systems.

Our Socialist world is definitely helping capitalism in one thing: to dig its grave the more quickly. Such are the facts of the "fruitful" competition of the two systems. ${ }^{18}$

Premier Khrushchev made this quite plain early this year when he stated that the Chinese Communists and the Soviet Communists had their disagreements on the correct line to follow during the present period, but that they both agreed that their basic policy was to bury capitalism. The Chinese and Soviets differ, and have since 1957 , on the risks of nuclear escalation from certain types of expansionist moves and on the advisability of waiting until the Soviets could gain greater strategic power to reduce these risks. ${ }^{14}$ They both look at international cooperation, however, as a tactic which can be used advantageously whenever it is called for by their respective strategic evaluations of the world situation.

One of the tactical uses which the Soviets make of their second basic space legal principle is indicated by the following statement of the Soviet representative to the U.N. Space Committee, Ambassador Platon Dimitrivich Morozov:

In any case in which discussion of international cooperation in any field takes place, it immediately becomes necessary to regulate the cooperation of the partics. Thercfore, how is it possible to speak of international cooperation in space research if the foundation is not laid, if those principles are not established which are basic to this cooperation. ${ }^{15}$

The Soviets make international cooperation contingent upon regulation, and regulation contingent upon U.S. acceptance of the space legal doctrines advanced by the Soviet Union. The space legal doctrines of the Soviet Union are manipulated to support the strategic position of the Soviet Union and to undermine the legality and political acceptability of the national and international security policies of the

${ }^{13}$ Solodovnikov, Speaking Different Languages, International Affairs (Moscow), No. $1 x$, at 46, 48.49, $52(1963)$.

16'This difference in revolutionary strategy is discussed in the author's article, Crane, The Sino-Sovieb Dispute on War and the Cuban Crisis, 8 OrB1s 537-49 (1964).

${ }^{15}$ Verbatim Record of the Tenth Meeting, Committee on the Peaceful Uses of Outer Space, Sept. 10, I962, at 61 (A/AC.I05/PV.ro). 
United States. ${ }^{10}$ The Soviets have tried to drive home the propaganda charge that any U.S. opposition to Soviet space legal doctrines is contrary to the requirements of "peaceful cooperation." By this tactic they are trying to brand the United States as an enemy of peace, and in turn to justify their own hostile activities. The duplicity of the Soviet use of the term "peaceful cooperation" is well illustrated by the fact that the above quoted statement by Morozov was made on September Io, I962, at the very time that the Soviets were suddenly and secretly establishing a strategic missile base in the heart of the Western Hemisphere roo miles from the state of Florida. ${ }^{17}$

\section{III}

\section{Disarmament}

The third basic principle of Soviet space law is "general and complete disarmament." This principle is discussed in the new Zhukov symposium. In his chapter entitled "Space Law as a Result of Technological Progress," M. I. Lazarev, who has for years been a principal interpreter of the interrelationship between Soviet military strategy and space law, states that "the most important goal in the development of space law will be the prevention of imperialist expansion and militarism in space." He attacks the counterforce doctrines of Secretary of Defense McNamara, which are designed to limit any nuclear war, if one should break out, to military targets, in order to provide the maximum incentive for both sides to stop the war before it could spread to cities. Soviet strategists oppose this doctrine primarily because it undercuts the Soviet use of the psychological threat that nuclear holocaust will be the inevitable result of any firm United States action against Communist expansionist moves. The relationship of space law to Secretary McNamara's strategy consists in the fact that the American strategy of counterforce was made possible to a large extent by the perfection of space observation satellites which indicate with a still considerable degree of reliability where the military targets, such as ICBMs, are in the Soviet Union. Lazarev warns that any attempt to legalize space observation satellites, or space interception and inspection, would lead to the creation of a Damocles sword hanging over mankind. He states that this would result because the U.S. satellites [which in our view are in the nature of arms control satellites designed to prevent war] are launched, as he puts it, "to facilitate the unleashing of aggressive, so-called preventive war ... against the socialist countries."18

${ }^{16}$ This manipulation of Sovict space legal doctrine is developed in detail in the author's article, Crane, Soviet Attitude Toward International Space Law, supra note ro.

${ }^{17}$ Analysis of Soviet negotiating tactics in the United Nations indicates that the obstructionist function of the unrealistic Soviet political demands in the U.N. disarmament committee is served in the U.N. space committee by the unrealistic Soviet preconditions for peaceful cooperation. It appears that recently the Soviets have started to mix their tactics by injecting some of their disarmament demands, such as the liquidation of foreign military bases, into the discussions in the U.N. Committee on the Peaceful Uses of Outer Space. See note 22 infra.

18 Lazarev, Space Law as a Result of Technological Progress (in Russian), Zhurov, op. cit. supra note $r$, at 163 . 
Lazarev states that space law and international space cooperation must be based on, and therefore are contingent upon, the prohibition of American military uses of space by the demilitarization and neutralization of outer space within the overall framework of what he calls "disarmament law."

This "disarmament law" had its genesis at the same time that the Soviets proclaimed the policy of "peaceful coexistence" during the mid-fifties. The Soviets attempt to provide a legal framework for their campaign for "general and complete disarmament" by interpreting the Charter of the United Nations to require the acceptance of the Soviet program of general and complete disarmament in order to fulfill the original goal of the United Nations, namely the creation of a world-wide system of collective security.

The Soviet writers on the law of disarmament, among whom the foremost is probably Mr. Bogdanov, base their attempt to create a new international legal principle of general and complete disarmament (GCD) on articles eleven and twenty-six of the United Nations Charter and on the unanimously approved Resolution 1378 of the Fourteenth Session of the U.N. General Assembly in 1959. Some Soviet jurists, among them Romanov, believe that neither articles eleven nor twentysix create a legal obligation for GCD but merely provide jurisdiction for the U.N. General Assembly and Security Council over GCD. Most Soviet lawyers, including Tunkin and Bogdanov, admit that Resolution $\times 378$, because of the nature of U.N. resolutions, cannot create a legal obligation. Therefore, the Soviets have embarked on a general campaign by their own efforts to create for their law of GCD the status of an accepted legal obligation.

They do this by insisting that the highest goal of mankind is the Soviet program for GCD and that this GCD therefore must be the original goal of the United Nations, though it was first announced as a Soviet foreign policy goal by Premier Khrushchev in 1959. Just as in their attempts to create an obligatory troika in the United Nations and in the International Court of Justice (an attempt which is repeated in the recent Zhukov space law book), the Soviets are attempting by their campaign of GCD to harness the entire United Nations and thereby the nations of the world to their own Soviet disarmament program.

The military advantages which the Soviets hope to gain from acceptance of its program of GCD are well known to disarmament negotiators. These derive mainly from the Soviet insistence on U.S. disarmament without the reliable inspection necessary to assure Soviet reciprocation; and from the Soviet insistence that in order to achieve GCD the United States must first agree to Soviet proposals to realign the power structure of the world under the guise of "reducing international tensions."

The first goal, i.e., U.S. disarmament, the Soviets hope to achieve by a psychological campaign designed to convince the peoples and leaders of the world that the future of mankind depends on American acceptance of disarmament without realistic inspection. This type of disarmament could result in unilateral disarmament of U.S. deterrent forces both through the voluntary destruction by the United States 
of its existing weapons and-more importantly-by the failure of the United States to modernize its weapons arensal. In a world of disarmament without realistic inspection, such a failure to modernize would permit the Soviets to win the technological arms race by getting a generation ahead in advanced weapons systems, particularly those which in the future may be most effectively used in outer space. This in turn would permit the Soviets in effect to force unilateral disarmament on the United States.

The nature of this Soviet goal has been explained by the Soviets often during the last half century and there is no evidence that this goal has changed. As early as IgI6, Lenin stated: "Only after the proletariat has disarmed the bourgeoisie will it be able, without betraying its world historical mission, to throw all armaments on the scraphead." In I928 the resolution of the Sixth World Congress of the Communist International emphasized that "The aim of the Soviet proposals for general and complete disarmament is to propagate the fundamental Marxian postulates that disarmament and the abolition of war are possible only with the fall of capitalism."

On January 6, I96r, Premier Khrushchev made the point that "The struggle for disarmament . . . is an effective struggle against imperialism." This struggle is also "an active struggle against imperialism," but above all it is an active struggle "for restricting its military potentialities."

On January 2, rg64, Pravda published the reply of Premier Khrushchev to the question, "What do you think should be done to ensure that atomic energy and the achievements of technology are used for the good of mankind." Khrushchev said: "The best solution of this problem is to get rid of all the social and national causes of the outbreak of any kind of war, a thing which can only be accomplished with the victory of socialism all over the world." It is noteworthy that one cannot accuse the Soviets of insincerity, because for those who take the trouble to study in detail Soviet policy on peaceful coexistence and disarmament, the Communists make it abundantly clear what they have in mind.

The second goal of the Soviet program of GCD which they have attempted to elevate to the level of international law is the requirement that prior to GCD the West must end the cold war. This was first put forth during the post-test ban period on November $8, \pi 963$, when the Soviet Union circulated a proposed amendment to a resolution which would urge the Geneva disarmament conference in January $\mathrm{Ig}_{4}$ to concentrate on tension reduction as a preliminary to disarmament. The Soviets wanted the United States to renounce the use of force of any kind in opposing Communist revolutions; to abandon its foreign bases and military commitments; to acknowledge Communist conquests, particularly in Central and Eastern Europe as permanent; and for good measure, to help the Communist world through trade, aid, and friendly relations to overcome its economic weaknesses and increase its political acceptability. Do all those things, say the Communists, and the cold war will end tomorrow. End the cold war and we can make progress on the most pressing problem of our time, namely general and complete disarmament. 
The present complete impasse in Geneva on the agenda, I believe, indicates what the United States thinks of this abuse of the desires of the world for peace and security. The new Soviet "disarmament law" is of vital importance as a basic principle of Soviet space law because the use of the Soviet GCD bargaining game has become the story of our failure to reach any really meaningful agreements in this area.

I shall not go into a discussion of the specific principles of Soviet space law. These include "liability for damages to the interests of other states," and "freedom of outer space." The latter was discussed particularly clearly by Cheprov in the recent Soviet space law symposium and by the Hungarian representative to the United Nations Space Committee on December 3, rg63 $^{10}$ Suffice it to say that agreement on these principles is explicitly conditioned on U.S. acceptance of the Soviet concept of peaceful coexistence and of the Soviet program of GCD.

This is particularly true for one of the most important of all Soviet general principles of space law: demilitarization and neutralization of outer space.

Whereas the Soviets prior to 1962 advocated the adoption of a legal principle calling for the use of space for peaceful uses only-and by this they meant nonmilitary purposes-this policy changed in 1962 to legalize military uses, and now has gone so far that the Soviets are beginning to designate even the attempt to inspect one of their military space satellites as an act of preventive war.

This Soviet policy of legalizing the military uses of space has been stated in increasingly plain terms by the Communist representatives to the U.N. Space Committee. On April 22, 1963, the Czechoslovakian delegate opposed the inclusion in a draft of space legal principles of a "provision prohibiting the use of outer space for war purposes." He added: "Practical implementation of . . . [article 2(4) of the Charter and operative paragraph I(a) of the General Assembly Resolution I72I (XVI) on the peaceful uses of space] could be ensured only by the negotiation and conclusion of an agreement on general and complete disarmament."20 On May 3, 1963 , the Soviet representative stated that the Soviet Union had adopted what he called a "realistic approach to the question and considered that the problem of the prohibition of the military use of outer space could be solved only in the context of disarmament." ${ }^{\text {.21 }}$

The Soviet representative stated his position quite clearly in the First Committee during the discussion on International Cooperation in the Peaceful Uses of Outer Space, on December 2, 1963, as follows:

The draft declaration does not and could not, of course, deal with the matter of military uses of outer space. As the members of the Committee all know, the Soviet Union has often stated that it is prepared, within the framework of a program of general and

\footnotetext{
${ }^{10}$ Verbatim Record, U.N. First Committee, Dec. 3, 1963, at 28 (A/C.r/PV.1343).

${ }^{20}$ Summary Record of the Twentieth Meeting, U.N. Committee on the Peaceful Uses of Outcr Space, Legal Subcommittee, April 22, I963, at 9 (A/AC.ro5/C.2/SR.20).

${ }_{21}$ Summary Record of the Twenty-eighth Meeting, U.N. Committee on the Peaccful Uses of Outer Space, Legal Subcommittce, May 3, 1963, at I4 (A/AC.I05/C.2/SR.28).
} 
complete disarmament under strict international control [which is the standard Soviet jargon], to destroy all types of weapons. That would also solve the problem of prohibiting the use of outer space for military purposes. However, we did not agree and still do not agree with attempts to divorce the matter of the military uses of outer space from other measures of disarmament which are intimately linked to it. As has been stated many times, the question of the prohibition of the use of outer space for military ends is organically linked with the question of the liquidation of foreign military bases on the territory of other countries. It is quite clear that the question of the prohibition of the military uses of outer space can be solved only in the context of disarmament, with parallel and simultaneous liquidation of foreign military bases on the territory of other countries. ${ }^{22}$

This statement acquires particular importance because it is the first time since the Cuban crisis that the Soviet representatives in the U.N. Space Committee have tied the demilitarization of outer space to the abolition of U.S. military bases.

On December 5, rg63, the Ukranian delegate went even further and stated that:

The representative of the United States declared that the above mentioned agreements on space "should help to create the confidence needed here on earth for greater progress in disarmament and cooperation in all areas." Without challenging this statement, we nevertheless would like to stress that the main question is that of general and complete disarmament and it is upon the way in which this problem is solved that, to a large extent, hinges the solution of other unsolved problems. ${ }^{23}$

In other places the Soviet representatives made possibly ominous remarks to the effect that the wording of the agreement over which the United States was rejoicing was broad enough to encompass all of the original points (except the prohibition of private enterprise in space) which the Soviets had used for two years since the inception of the U.N. Space Committee to block all progress in the development of space law. ${ }^{24}$ The clearest statement was made a year earlier, on December Io, Ig62, during the post-Cuban detente by the Soviet representative who stated that the militarization of space could be overcome only by the "liquidation of the cold war," of course on Communist terms.

During the fall $\mathrm{I}_{96} 6_{3}$ session of the U.N. Space Committee, Academician Blagonrarov commented on September Io, 1963 that after the test ban treaty "the Soviet delegation considers it essential once more to stress the importance of a com-

\footnotetext{
${ }^{22}$ Verbatim Record, U.N. First Committee, Dec. 2, I963, at $4 \mathrm{I}-42$ (A/C.r/PV.r343).

${ }^{33}$ Verbatim Record, U.N. First Committee, Dec. 5, 1963, at 43-45 (A/C.1/PV.1345). (Emphasis added.)

26 Provisional Verbatim Record of the Twenty-fourth Meeting, U.N. Committee on the Peaceful Uses of Outer Space, Nov. 22, 1963, at 5I (A/AC.105/PV.24). The provisional record includes the statement: "The draft includes the most important basic legal principles which, one way or another, were touched upon in the course of the work of our Committee and of the Legal Subcommittee. That is why, as has been stated here, the draft . . . will, we hope, meet the interests of all the Member States of the United Nations." In the Additional Report of the Committee on the Peaceful Uses of Outer Space, Nov. 27, 1963 (A/5549/Add.r), this wording was changed to read: "The draft includes important basic legal principles...." On Dec. 2, 1963, the Soviet delegate used the following wording: "In it we find reflected most important fundamental legal principles which are mentioned in various guises luring the discussion on this matter. Verbatim Record, U.N. First Committee, Dec. 2, 1963, at 37 (A/C.I/PV/I342).
} 
plete solution of this question that prevents the arbitrary holding of space research and experiments...."25 Three days later, on September 13, I963, he made the statement that the test ban treaty had "removed the possibility of harmful experiments in outer space for the time being." 26

The most startling of all statements on the military uses of outer space ever made by a responsible Soviet citizen is contained in the introductory chapter of the Zhukov symposium on space law. Zhukov indicated, as he first did in August $1962,{ }^{27}$ that space observation is aggressive, but bombs in orbit are not. He stated that self-defense under article fifty-one of the U.N. Charter does not permit the interception of bombs in orbit because the mere presence of bombs in orbit does not constitute the necessary armed attack. He then proceeded to develop a new and remarkable principle of Soviet space law, namely that if a state finds out that the satellite of another country contains a nuclear bomb, any attempt to disable it would constitute an act of "preventive war." The strategic significance of this term consists in the fact that for the Soviets, knowledge of an impending preventive war is a legitimate cause for a just pre-emptive attack on the United States. This statement is undoubtedly designed as an attempt at psychological warfare to instill in U.S. readers the proper fear of nuclear escalation resulting from any American attempts at countermeasures, for example, through the explosion of a nuclear bomb in the vicinity of the bomb in orbit.

One of the reasons given for this new Soviet space legal principle is the difficulty, within the current state of the art, reliably to inspect space satellites. Zhukov states: Under conditions where it is practically impossible to determine the character of the activity of a space apparatus, the recognition of the right of a state to capture the apparatus for inspection would be tantamount to the assertion of complete arbitrariness and lack of law in this new sphere of human activity. How would one have any guarantee that space ships with a cosmonaut on board following exclusively peaceful purposes would not be destroyed by a state which considered that it endangered its security. ${ }^{28}$

This reasoning is most interesting in view of the recent Soviet indication that the Soviets must push space military research and development and that "it is necessary to have suitable means of providing for the timely detection of space apparatuses of the enemy and for their rapid destruction or neutralization.."20 In

${ }^{25}$ Verbatim Record of the Twenty-first Meeting, U.N. Committec on the Peaccful Uses of Outer Space, Sept. 1o, 1963 , at $4 \mathrm{r}$ (A/AC.105/PV.2I).

${ }^{28}$ Verbatim Record of the Twenty-second Meeting, U.N. Committec on the Pcaceful Uses of Outer Space, Sept. 13, 1963, at 45-50 (A/AC.105/PV.22). (Emphasis added.)

${ }^{27}$ See Crane, The Beginnings of Marxist Space Jutrisprudence, 57 AM. J. INT'2 L. 615, 622 (1963).

${ }^{28}$ Zhukov, The Legal Regime of Outer Space in the Contemporary Period (in Russian), Znurov, op. cit. supra note I, at 33 .

${ }^{20}$ v. D. Sokolovskiy (Marshat of the Soviet Union) (Ed.), Voyennaya Strategrya (Military Strategy) 395 (2d ed. 1963). The means which the Soviets may have in mind are indicated by another reference in this book which emphasizes the importance of electro-magnetic warfare for the "destruction or jamming of the electronic fuses of bombs and missiles by electronic radiation, and the interception of radio signals and generation of interference in the electronic equipment for acrial reconnaissance, ravigation, bombing, and in-flight missile guidance." Soviet MiLitary Strutecy 337-38 
other words, the Soviets are preparing for the interception and destruction of U.S. satellites but assert that similar action by the United States against Soviet satellites would be an act of preventive war.

\section{Conclusion}

This inconsistency is understandable only if one understands that the Soviets use international law not as a means to resolve and remove conflict, but rather to manage and direct conflict in the interests of Communist global expansion. The Soviets have orchestrated the manipulation of both legal and military doctrines so that they serve really as two sides of the same coin. They are merely two different aspects of the single discipline of conflict management. The principles of Soviet space law, including the three most basic principles of peaceful coexistence, peaceful cooperation, and disarmament, are fully understandable only within this framework of analysis.

(translated and with analytical introduction and annotations by Herbert S. Dinerstein, Leon Goure \& Thos. W. Wolfe, r963). The Soviets are referring to electronic countermeasures to disable the circuitry of ICBMs passing through space and to de-trigger their warheads. In the revised edition of this book, published in August 1963, the Soviets also for the first time called attention to U.S. research in the military use of anti-gravitation, anti-matter, plasma and lasers. See id. 394, 405 (2d ed. I963). 